\title{
クォータニオンを用いたフィードフォワード オンラインポーズ遺伝的認識法
}

宋 薇*1 見 浪護*1 青 柳 誠 司*2

\section{Feedforward On-line Pose Evolutionary Recognition Based on Quaternion}

\author{
Wei Song*1, Mamoru Minami*1 and Seiji Aoyagi*2
}

\begin{abstract}
This paper presents an on-line pose measurement method of a 3D object. The proposed method utilizes an on-line evolutionary search technique of the genetic algorithm (GA) in pattern recognition and a fitness evaluation based on matching input dynamic images with stereo models whose poses are expressed by unit quaternion. To improve the dynamics of recognition, a motion-feedforward compensation method is proposed for the hand-eye system by predicting target object's motion in camera frame induced by the hand-eye motion through the kinematic calculation of robot's motion. The effectiveness of the proposed method is confirmed by simulation experiments.
\end{abstract}

Key Words: Pose Measurement, Unit Quaternion, GA, Motion-feedforward Compensation

\section{1. 緒言}

物体認識を応用するロボットビジョンの分野では, ビジュアル サーボと呼ばれる画像処理結果をロボットのフィードバック情 報として用いる運動制御が最近注目されている $[1] 〜[4]$. ビジュ アルサーボはフィードバックループ内部に視覚センサを含むた め, 視覚センサの認識時間の遅れが問題となる。この時間遅れ を防ぐため，物体の運動モデルと非線形オブザーバを導入する ことによって, 物体の運動を予測する手法 [5] が提案されたが, 認識誤差がゼロ近くまで減少するまでにある程度の時間がかか るという問題は残っている. この方法は, 動力学モデルに誤差 が含まれる実際のビジュアルサーボ系では, 制御系が不安定に なる可能性がある，また，オブザーバを用いると，高次の運動 モデルに対して演算量が多くなるという欠点もある。 Luca ら は非線形オブザーバを用いて，既知のカメラの運動からカメラ から対象物までの距離 “Z”值を推定する方法を提案した [6]. ᄂ かし，初期時刻では正しく推定できず，ある時間経過の後 “Z” 值の推定誤差は次第に減少する。 また，この方法は単眼を用い るため既知のカメラの運動による移動視が必要であり, ハンド が動かないカメラ固定の状態では “Z”值を推定できない.一方, 一般的な CCD カメラのサンプリング周期は $33[\mathrm{~ms}]$, 関節サー ボ系のサンプリング周期は $1[\mathrm{~ms}]$ 程度とこれらの間には大きな

\footnotetext{
原稿受付 2008 年 1 月 27 日

*1福井大学

$* 2$ 関西大学

${ }^{* 1}$ University of Fukui

${ }^{* 2}$ Kansai University

口 本論文は学術性で評価されました。
}

差がある. サンプリング周期が $1[\mathrm{~ms}]$ と非常に高速な画像処理 を行うことができるビジョンチップを用いると予測や補償など を用いなくても，高速移動物体の追従が可能になる $[7][8]$. し かし，この高速ビジョンシステムは高価である.

画像による三次元位置/姿勢計測を行う方法は，大きく二つ の手法に分けられる。一つは, 画像中の幾何学的特徴, 例えば 点, 線, エッジなどの領域を抽出して, これの対応づけにより三 次元計測を行う特徴量ベース手法であり, 今までにステレオ対 応点探索処理に関して様々な手法が提案されている [9] [10]. 欠 点としては左右カメラ画像内の対応点の認識が困難な場合があ り, 計測誤差の発生原因となる。一方，対象物形状を利用した モデルと画像との照合による計測手法がある。これは, 物体の 姿勢変化などによる画像中の物体形状に対し, 同一物体の多く の姿勢に基づく写真画像を多数教示しておき，どの写真画像が 入力画像と一致するかを決定するという手法で, アピアランス ベース手法と呼ばれる, 特徵モデルを用意する必要がなく, 左右 画像の対応点問題も発生しない. また, 幾何学的に複雑な形状 の認識なども容易に行うことができるという特徴から近年，ア ピアランスベースでの物体認識が盛んに行われている [11] [12]. しかし, この手法は大きなメモリを必要とし, マッチングに時 間がかかるので，速く効率的な計測をすることができない，ア ピアランスベース手法と似た方法ではあるが，より計算時間を 少なくすることができるモデルベース手法がある. 対象物に基 づいて作成したモデルと画像との照合による三次元認識を行う 手法である [13] [14].

本研究では, 複眼を持つハンドアイマニピュレータが運動中 に対象物の三次元位置/姿勢を認識するとき, 認識の時間遅 
れを減少させ，認識ダイナミクスを改善するための MotionFeedForward (MFF) と呼ぶ補償方法を提案する. ビジュアル サーボ時のロボットの動きを認識部にフィードフォワードする ことによって, 認識系はハンドアイの位置/姿勢の運動に影響 されないという特徴を持つ. MFF を用いて, 物体の真の運動 とハンドアイが動くことによる相対的な運動を計測部が区別す ることができるため, 文献 [6] と異なり初期時刻からロボットの 動きによって発生する対象物の画像内の見かけ上の運動を予測 できる。この MFF 補償法は, 非線形オブザーバの推定システ ムに組み組むことで，ハンドアイの動視点による影響を静視点 での推定特性に向上させる可能性を持っている.

本報での三次元計測手法はモデルベース手法に含まれる [15] [16]. 特徵量べース手法と違い左右画像の対応点を探索す る必要はない. 本研究では, クォータニオンを用いて対象物や 立体モデルの姿勢を表す，クォータニオンは，オイラー角やア ングル/アクシス表現の特異姿勢問題を解決できる姿勢表現で, ビジュアルサーボの安定性の証明に有効である [17]. クォー夕 ニオンで表された対象物の三次元ポーズの候補は, 遺伝的アル ゴリズム（GA）の遺伝子として表現される，遺伝子はモデル と入力画像の相関関数を適合度として最適化することで進化し, 入力画像中の対象物とモデルのポーズが一致していく.

GA は収束するまでにある程度の時間を必要とするため, 一般 には実時間処理が必要なオンライン計測には用いられてこなかっ た.この GAのリアルタイム性の問題に対し, “1-Step GA”を 適用する，筆者らは泳ぐ魚をロボットにより捕獲する研究事例 より“1-Step GA”を用いた実時間認識が可能であることを示 した $[18]$.

一方, 従来画像マッチングによる位置・姿勢計測はマッチン グを評価する正定值関数のテーラー展開を用い，その線形近似 により最適化を行い計測していた [19]〜 [23]. この場合, 解近傍 領域で近似が正当化される範囲でのみ計測可能であるという制 約を伴っていた，つまり単峰性が保証される領域内での最適化 による計測であった。これに対して本報の“1-Step GA”によ る最適化は多峰性関数に対しても有効であり, 単峰性を制約条 件としない.

\section{2. 姿勢の数式による表現}

ここでは, クォータニオンを用いた姿勢表現について述べる. 三次元空間に打ける姿勢表現はいくつもの方法が考えられてい る. その最もよく知られ用いられているものが, Euler angles である. オイラー角は最少変数で姿勢を表現できるものの, 表 現上の特異姿勢が同様に存在するという重大な欠点がある.

四つのパラメータ, すなわち正規化された回転軸 $\boldsymbol{k}$ とその回 りの回転角 $\theta$ で姿勢を表す方法がある。これは, angle/axis 表 現と呼ばれる。この方法は, 回転軸 $\boldsymbol{k}$ と回転角 $\theta$ で表した姿 勢と回転軸 $-\boldsymbol{k}$ と回転角 $-\theta$ で表した姿勢が一致する。また, $\theta=0$ のとき, $\boldsymbol{k}$ は不定となる. これらの任意性は姿勢制御の安 定性の解析に不都合であり，ビジュアルサーボに不向きである。

上記の問題を解決する姿勢表現が, Quaternion (4 元数) で ある.この Quaternion の利点から, 三次元剛体の姿勢制御や ロボットマニピュレータ制御などに適応する研究が盛んに行わ
れている $[24] 〜[26]$. 以下では，本報で用いる基礎式を述べる，

Quaternion は angle/axis 表現の $\boldsymbol{k}(\|\boldsymbol{k}\|=1), \theta$ を用いて， 次のように定義される.

$$
\begin{gathered}
\boldsymbol{Q}=\{\eta, \boldsymbol{\epsilon}\}, \\
\eta=\cos \frac{\theta}{2}, \quad \boldsymbol{\epsilon}=\sin \frac{\theta}{2} \boldsymbol{k},
\end{gathered}
$$

式 (2) より, $\eta$ と $\boldsymbol{\epsilon}$ は次のユニットクォータニオン条件を満 たす.

$$
\eta^{2}+\boldsymbol{\epsilon}^{T} \boldsymbol{\epsilon}=1
$$

式（3）に示すように $\boldsymbol{\epsilon}$ から $\eta$ を導出できるため, 姿勢を表す 独立変数は $\boldsymbol{\epsilon}$ だけである. angle/axis 表現と違い, 回転軸 $\boldsymbol{k}$ と回転角 $\theta$ で表したクォータニオンと回転軸 $-\boldsymbol{k}$ と回転角 $-\theta$ で表したものは一致し, angle/axis 表現の任意性は解決されて いる. また, $\theta=0$ のとき, $\boldsymbol{\epsilon}=\mathbf{0}, \eta=1$ となり, $\boldsymbol{k}$ が不定 となった angle/axis の問題は解消されており, クォータニオン を用いるとき $\pi<\theta<\pi$ の範囲で表現上の特異姿勢の問題は ない。

クォータニオンに対応する回転行列 $\boldsymbol{R}$ は次のように表され る $[17]$.

$$
\boldsymbol{R}(\eta, \boldsymbol{\epsilon})=\left(\eta^{2}-\boldsymbol{\epsilon}^{T} \boldsymbol{\epsilon}\right) \boldsymbol{I}+2 \boldsymbol{\epsilon} \boldsymbol{\epsilon}^{T}+2 \eta \boldsymbol{S}(\boldsymbol{\epsilon})
$$

ここで, $\boldsymbol{I}$ は $3 \times 3$ の単位行列である。記号 $\boldsymbol{S}(\cdot)$ は, ベクト ルの外積演算を行列で表現している.

一方，任意の回転行列 $\boldsymbol{R}=\left\{R_{i, j}\right\},(i, j=1,2,3)$ に対応す るクォータニオンは次のように表される.

$$
\begin{gathered}
\eta=\frac{1}{2} \sqrt{1+R_{11}+R_{22}+R_{33}} \\
\boldsymbol{\epsilon}=\frac{1}{2}\left[\begin{array}{l}
\operatorname{sgn}\left(R_{32}-R_{23}\right) \sqrt{R_{11}-R_{22}-R_{33}+1} \\
\operatorname{sgn}\left(R_{13}-R_{31}\right) \sqrt{R_{22}-R_{33}-R_{11}+1} \\
\operatorname{sgn}\left(R_{21}-R_{12}\right) \sqrt{R_{33}-R_{11}-R_{22}+1}
\end{array}\right]
\end{gathered}
$$

さらに, クォータニオンの時間微分と角速度ベクトル $\boldsymbol{\omega}$ との 間には以下のような関係が成立する $[17]$.

$$
\begin{gathered}
\dot{\eta}=-\frac{1}{2} \boldsymbol{\epsilon}^{T} \boldsymbol{\omega} \\
\dot{\boldsymbol{\epsilon}}=\frac{1}{2}(\eta \boldsymbol{I}-\boldsymbol{S}(\boldsymbol{\epsilon})) \boldsymbol{\omega}
\end{gathered}
$$

\section{3. ロボットアーム（PA10）のダイナミクス}

ここでは，4 章で提案する Motion-Feedforward（MFF）法 の効果を確認する準備のため, マニピュレータのロボットのダ イナミクスとハンドの軌道追従制御系を記述しておく.

本報で使用するマニピュレータは三菱重工製ロボットアーム （PA10）のモデルである. Fig. 1 に示すように，ロボットの基 準座標系 $\Sigma_{W}$, ハンドの手先座標系 $\Sigma_{E}$, 右のカメラの座標系を $\Sigma_{C R}$, 物体の座標系 $\Sigma_{M}$ と定義する. $\Sigma_{E}$ と $\Sigma_{C R}$ は一致する と仮定する。まだ次章以後で用いるロボット手先の位置/姿勢, 
Table 1 Object/end-effector's pose definitions

\begin{tabular}{|c|c|}
\hline Desired end-effector's trajectory in $\Sigma_{W}$ : & ${ }^{W} \boldsymbol{\psi}_{E d}(t)=\left[{ }^{W} x_{E d},{ }^{W} y_{E d},{ }^{W} z_{E d},{ }^{W} \epsilon_{1 E d},{ }^{W} \epsilon_{2 E d},{ }^{W} \epsilon_{3 E d}\right]^{T}$ \\
\hline End-effector's pose in $\Sigma_{W}$ : & ${ }^{W} \boldsymbol{\psi}_{E}(t)=\left[{ }^{W} x_{E},{ }^{W} y_{E},{ }^{W} z_{E},{ }^{W} \epsilon_{1 E},{ }^{W} \epsilon_{2 E},{ }^{W} \epsilon_{3 E}\right]^{T}$ \\
\hline Object's pose in $\Sigma_{C R}$ : & ${ }^{C R} \boldsymbol{\psi}_{M}(t)=\left[{ }^{C R} x_{M},{ }^{C R} y_{M},{ }^{C R} z_{M},{ }^{C R} \epsilon_{1 M},{ }^{C R} \epsilon_{2 M},{ }^{C R} \epsilon_{3 M}\right]^{T}$ \\
\hline Individual of GA in $\Sigma_{C R}$ when not using MFF: & $\mathrm{i}$ : generation, $\mathrm{j}$ : individual \\
\hline Detected object's pose in $\Sigma_{C R}$ by "1-step GA": & ${ }^{C R} \hat{\boldsymbol{\psi}}_{M}(t)=\left[{ }^{C R} \hat{x}_{M},{ }^{C R} \hat{y}_{M},{ }^{C R} \hat{z}_{M},{ }^{C R} \hat{\epsilon}_{1 M},{ }^{C R} \hat{\epsilon}_{2 M},{ }^{C R} \hat{\epsilon}_{3 M}\right]^{T}$ \\
\hline Individual of GA in $\Sigma_{C R}$ when using MFF: & $\mathrm{i}$ : generation, $\mathrm{j}$ : individual \\
\hline Detected object's pose in $\Sigma_{C R}$ by "MFF +1 -step GA": & ${ }^{C R} \hat{\boldsymbol{\psi}}^{\star}{ }_{M}(t)=\left[{ }^{C R} \hat{x}^{\star}{ }_{M},{ }^{C R} \hat{y}^{\star}{ }_{M},{ }^{C R} \hat{z}^{\star}{ }_{M},{ }^{C R} \hat{\epsilon}^{\star}{ }_{1 M},{ }^{C R} \hat{\epsilon}^{\star}{ }_{2 M},{ }^{C R} \hat{\epsilon}^{\star}{ }_{3 M}\right]^{T}$ \\
\hline
\end{tabular}

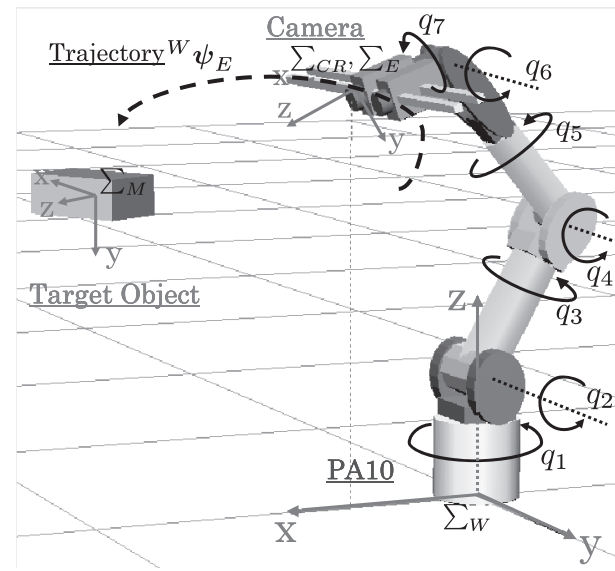

Fig. 1 Visual servo system of PA-10

物体の位置／姿勢に関するパラメータの定義を Table 1 に示す. ロボットアーム全体は 7 自由度であり, 運動方程式は

$$
\boldsymbol{M}(\boldsymbol{q}) \ddot{\boldsymbol{q}}+\boldsymbol{h}(\boldsymbol{q}, \dot{\boldsymbol{q}})+\boldsymbol{g}(\boldsymbol{q})=\boldsymbol{\tau}
$$

と表される。ここで, $\boldsymbol{q}$ は関節角度 $\boldsymbol{q}=\left[q_{1}, q_{2}, \cdots, q_{7}\right]^{T}, \boldsymbol{\tau}$ は 関節駆動トルク $\boldsymbol{\tau}=\left[\tau_{1}, \tau_{2}, \cdots, \tau_{7}\right]^{T}, \boldsymbol{M}(\boldsymbol{q})$ はロボットアー 厶の慣性行列, $\boldsymbol{h}(\boldsymbol{q}, \dot{\boldsymbol{q}})$ は遠心力・コリオリ力に関するべクト ル, $\boldsymbol{g}(\boldsymbol{q})$ は重力ベクトルである.

$\boldsymbol{\tau}$ はPD 制御による決定される。

$$
\boldsymbol{\tau}=\boldsymbol{D}_{p}\left(\boldsymbol{q}_{d}-\boldsymbol{q}\right)+\boldsymbol{D}_{d}\left(\dot{\boldsymbol{q}}_{d}-\dot{\boldsymbol{q}}\right),
$$

ここで, $\boldsymbol{D}_{p}$ はバネ定数, $\boldsymbol{D}_{d}$ は粘性抵抗を表す行列である.

手先の目標軌道 ${ }^{W} \boldsymbol{\psi}_{E d}(t)=\left[{ }^{W} \boldsymbol{r}_{E d}^{T},{ }^{W} \boldsymbol{\epsilon}_{E d}^{T}\right]^{T}$ と定義し（Table 1 参照 $),{ }^{W} \boldsymbol{\psi}_{E d}(t), t \in[0, T]$ が与えられた場合に, 実現す る関節変数 $\boldsymbol{q}_{d}(t)$ を逆運動学問題を用いて解く.

$$
\boldsymbol{q}_{d}(t)=\boldsymbol{f}^{-1}\left({ }^{W} \boldsymbol{\psi}_{E d}(t)\right) .
$$

手先目標速度 ${ }^{W} \dot{\boldsymbol{\psi}}_{E d}(t)$ を実現する関節速度 $\dot{\boldsymbol{q}}_{d}(t)$ はヤコビ行 列を用いて式

$$
\dot{\boldsymbol{q}}_{d}(t)=\boldsymbol{J}^{+}(\boldsymbol{q})^{W} \dot{\boldsymbol{\psi}}_{E d}(t) .
$$

で求められる.ここで $\boldsymbol{J}^{+}(\boldsymbol{q})=\boldsymbol{J}^{T}\left(\boldsymbol{J} \boldsymbol{J}^{T}\right)^{-1}$ である.

\section{4. “1-step GA”による実時間認識}

基準座標系 $\Sigma_{W}$ から対象物に固定した座標系 $\Sigma_{M}$ へのベク
トルを $\Sigma_{W}$ で表したものを ${ }^{W} \boldsymbol{r}_{M}$ ，同様に $\Sigma_{W}$ から右カメラ 座標系 $\Sigma_{C R}$ へのベクトルを ${ }^{W} \boldsymbol{r}_{C R}$ とする。 また $\Sigma_{C R}$ から $\Sigma_{M}$ へのベクトルを $\Sigma_{C R}$ で表したものを $\boldsymbol{r}_{M}$ とする。 またそ の姿勢を $\boldsymbol{\epsilon}_{M}$ と表す．位置・姿勢をまとめて $\boldsymbol{\psi}_{M}=\left[\boldsymbol{r}_{M}^{T}, \boldsymbol{\epsilon}_{M}^{T}\right]^{T}$ と表す (Table 1 参照). 表記を簡潔にするため, 以後左上添え 字のない変数は $\Sigma_{C R}$ を基準に表しているものとする.

認識対象物の正確な形状情報が認識系に与えられているとき, 位置・姿勢 $\psi_{M}$ に存在する対象物モデルと入力画像との相関関 数を $S\left(\boldsymbol{\psi}_{M}\right)$ と表す [15] [16]. $\boldsymbol{\psi}_{M}$ を変数とするとき, 時刻 $t$ における相関 $S\left(\boldsymbol{\psi}_{M}(t)\right)$ の最大值を与える $\boldsymbol{\psi}_{M}^{\max }$ は,

$$
\boldsymbol{\psi}_{M}^{\max }(t)=\left\{\boldsymbol{\psi}_{M}(t) \mid \max _{\boldsymbol{\psi}_{M}(t) \in L} S\left(\boldsymbol{\psi}_{M}(t)\right)\right\}
$$

と表される。 $L$ は $\boldsymbol{\psi}_{M}(t)$ が取り得る位置・姿勢空間であ る. 次に時刻 $t$ に GAによって求められた $j$ 番目の遺伝子 $\boldsymbol{\psi}_{M, G A, j}(t),(j=1,2, \cdots, p)$ のなかで最大の $S$ を与える遺伝 子 $\boldsymbol{\psi}_{M, G A}^{\max }(t)$ を

$$
\begin{aligned}
\boldsymbol{\psi}_{M, G A}^{\max }(t)= & \left\{\boldsymbol{\psi}_{M, G A, j}(t) \mid\right. \\
& \boldsymbol{\psi}_{M, G A, j}(t) \in L
\end{aligned}
$$

と表す. GA の進化計算では $S\left(\boldsymbol{\psi}_{M, G A, j}(t)\right)$ を $j$ 番目の遺伝 子の適合度関数として用いている. 時刻 $t$ の $S$ の最大值を与 える $\boldsymbol{\psi}_{M}^{\max }(t)$ と GA の最大值を与える $\boldsymbol{\psi}_{M, G A}^{\max }(t)$ との差を $\delta \boldsymbol{\psi}(t)=\boldsymbol{\psi}_{M}^{\max }(t)-\boldsymbol{\psi}_{M, G A}^{\max }(t)$ と表し, $\Delta S(\delta \boldsymbol{\psi}(t))$ を次式で 定義する.

$$
\Delta S(\delta \boldsymbol{\psi}(t))=S\left(\boldsymbol{\psi}_{M}^{\max }(t)\right)-S\left(\boldsymbol{\psi}_{M, G A}^{\max }(t)\right)
$$

このとき, 式（13）（14）より $\Delta S(\delta \boldsymbol{\psi}(t)) \geq 0$ であることは自 明であるが, さらに[仮定 (1) ] : $S\left(\boldsymbol{\psi}_{M}(t)\right)$ は $\delta \boldsymbol{\psi}(t)=\mathbf{0}$ の ときのみ $\Delta S(\delta \boldsymbol{\psi}(t))=\mathbf{0}$ が成立する分布であることを仮定す る。これは, 認識モデルを正確に作成すること, 相関関数 $S$ を 注意深く作成すること, 画像計測に適した証明条件を用意する こと, さらに認識対象物の形と似ている形状の物体をカメラ撮 像範囲に配置しないなどに注意すれば, 仮定（1）は実現可能で ある $[18]$.

さらに [仮定 $(2)]: S\left(\boldsymbol{\psi}_{M}^{\max }(t)\right), S\left(\boldsymbol{\psi}_{M, G A}^{\max }(t)\right)$ が時間 $t$ に 関して微分可能であり,

$$
\dot{S}\left(\boldsymbol{\psi}_{M, G A}^{\max }(t)\right)>\dot{S}\left(\boldsymbol{\psi}_{M}^{\max }(t)\right)
$$


が成り立つことを仮定する。これは時変分布関数のピークの移 動速度より GA のピークへの収束速度が速いという条件である. この条件の成立に関して, 相関関数 $S(\boldsymbol{\psi}(t))$ の分布形状, 対 象物の移動速度, 画像計測コンピュータの計算速度, カメラ動 画像の入力速度, GA のパラメータの設定などが $\dot{S}\left(\boldsymbol{\psi}_{M}^{\max }(t)\right)$, $\dot{S}\left(\boldsymbol{\psi}_{M, G A}^{\max }(t)\right)$ に関係している. ここでは対象物の想定される 移動速度を上回る計算能力を持つコンピュータを使用すること を前提とし仮定（2）は実現できるものと考える。また静止画 が与えられるとき $\dot{S}\left(\boldsymbol{\psi}_{M}^{\max }(t)\right)=0$ であるから, 式 (16) より $\dot{S}\left(\boldsymbol{\psi}_{M, G A}^{\max }(t)\right)>0$ であり, これは GA が単調に収束すること を意味する。本報では GA の進化はエリート保存戦略を採用し ていることで正当化される，仮定（2）が成立するとき式（15） より $\Delta \dot{S}(\delta \boldsymbol{\psi}(t)) \leq 0$ である.

したがって仮定（1），仮定（2）が成立するとき $\Delta S(\delta \boldsymbol{\psi}(t))$ はリアプノフ関数であり, $\delta \boldsymbol{\psi}(t)=\mathbf{0}$ は位置・姿勢空間 $L$ にお いて漸近安定である。このとき

$$
\boldsymbol{\psi}_{M, G A}^{\max }(t) \longrightarrow \boldsymbol{\psi}_{M}^{\max }(t) \quad(t \longrightarrow \infty)
$$

であるため，実時間最適化が可能なことが分かる。このときあ る有界な時刻 $t$ においては $\boldsymbol{\psi}_{M, G A}^{\max }(t)$ は最適解 $\boldsymbol{\psi}_{M}^{\max }(t)$ のあ る近傍

$$
\delta \boldsymbol{\psi}(t)=\boldsymbol{\psi}_{M}^{\max }(t)-\boldsymbol{\psi}_{M, G A}^{\max }(t) \leq \epsilon, \quad(\epsilon>0)
$$

に存在することが保証される. 上式のように実時間画像計測に おいて, 計測誤差がある值 $\epsilon$ 以下であることを保証し, GA の 収束を待つことなく時刻 $t$ の准最適解 $\boldsymbol{\phi}_{M, G A}^{\max }(t)$ を時刻 $t$ の実 時間最適化問題の解として取り扱う手法を「1-step GA」と呼 んでいる，筆者らの今までの研究で「1-step GA」により実時 間最適化問題を解くことで, 画像より対象物の位置・姿勢を計 測し続けることができることは確認されており [16] [18], 上記 仮定 (1), 仮定（2）が実現可能な仮定であると考えている.

\section{Motion-Feedforward (MFF) 法}

カメラ座標系 $\Sigma_{C R}$ で表した対象物の位置 $\boldsymbol{r}_{M}$ はカメラの位 置 ${ }^{W} \boldsymbol{r}_{C R}$ と対象物の位置 ${ }^{W} \boldsymbol{r}_{M}$ によって次式で表される.

$$
\boldsymbol{r}_{M}=\boldsymbol{R}_{W}(\boldsymbol{q})\left({ }^{W} \boldsymbol{r}_{M}-{ }^{W} \boldsymbol{r}_{C R}(\boldsymbol{q})\right) .
$$

式（19）を時間について微分すると

$$
\begin{aligned}
\dot{\boldsymbol{r}}_{M}= & \boldsymbol{R}_{W}(\boldsymbol{q})\left({ }^{W} \dot{\boldsymbol{r}}_{M}-{ }^{W} \dot{\boldsymbol{r}}_{C R}\right)+\boldsymbol{S}\left(\boldsymbol{\omega}_{W}\right) \\
& \boldsymbol{R}_{W}(\boldsymbol{q})\left({ }^{W} \boldsymbol{r}_{M}-{ }^{W} \boldsymbol{r}_{C R}(\boldsymbol{q})\right) .
\end{aligned}
$$

次に回転速度に関して, $\Sigma_{W}$ から見たカメラ座標系 $\Sigma_{C R}$, 物 体座標系 $\Sigma_{M}$ の角速度を ${ }^{W} \boldsymbol{\omega}_{C R},{ }^{W} \boldsymbol{\omega}_{M}$ とするとき

$$
\boldsymbol{\omega}_{M}=\boldsymbol{R}_{W}(\boldsymbol{q})\left({ }^{W} \boldsymbol{\omega}_{M}-{ }^{W} \boldsymbol{\omega}_{C R}\right)
$$

姿勢速度 $\dot{\boldsymbol{\epsilon}}_{M}$ と回転角速度 $\boldsymbol{\omega}_{M}$ との関係は式（8）より

$$
\dot{\boldsymbol{\epsilon}}_{M}=\frac{1}{2}\left[\eta_{M} \boldsymbol{I}-\boldsymbol{S}\left(\boldsymbol{\epsilon}_{M}\right)\right] \boldsymbol{\omega}_{M}
$$

護 青 柳 誠 司

カメラの速度はヤコビ行列 $\boldsymbol{J}(\boldsymbol{q})=\left[\boldsymbol{J}_{P}^{T}(\boldsymbol{q}), \boldsymbol{J}_{O}^{T}(\boldsymbol{q})\right]^{T}$ を用い て表現できる。ここで, 手先の並進速度と関節速度との関係を 表したヤコビ行列の上 3 行を $\boldsymbol{J}_{P}(\boldsymbol{q})$, 手先の回転角速度と関節 速度との関係を表したヤコビ行列の下 3 行を $\boldsymbol{J}_{O}(\boldsymbol{q})$ と表現す る。このとき, 次式が成り立つ。

$$
\begin{gathered}
{ }^{W} \dot{\boldsymbol{r}}_{C R}=\boldsymbol{J}_{P}(\boldsymbol{q}) \dot{\boldsymbol{q}} \\
{ }^{W} \boldsymbol{\omega}_{C R}=\boldsymbol{J}_{O}(\boldsymbol{q}) \dot{\boldsymbol{q}} \\
\boldsymbol{S}\left(\boldsymbol{\omega}_{W}\right)=-\boldsymbol{R}_{W}(\boldsymbol{q}) \boldsymbol{S}\left({ }^{W} \boldsymbol{\omega}_{C R}\right)^{W} \boldsymbol{R}_{C R}(\boldsymbol{q}) \\
=-\boldsymbol{R}_{W}(\boldsymbol{q}) \boldsymbol{S}\left(\boldsymbol{J}_{O}(\boldsymbol{q}) \dot{\boldsymbol{q}}\right)^{W} \boldsymbol{R}_{C R}(\boldsymbol{q}) .
\end{gathered}
$$

式（25）の導出については付録 1 に示した. 式（23）（25）を 用いて式 (20)（22）を書き直すと, カメラから見た対象物の速 度 /姿勢速度は,

$$
\begin{aligned}
\dot{\boldsymbol{\psi}}_{M}= & {\left[\begin{array}{c}
\dot{\boldsymbol{r}}_{M} \\
\dot{\boldsymbol{\epsilon}}_{M}
\end{array}\right] } \\
= & {\left[\begin{array}{c}
-\boldsymbol{R}_{W}(\boldsymbol{q}) \boldsymbol{J}_{P}(\boldsymbol{q})+\boldsymbol{R}_{W}(\boldsymbol{q}) \\
\boldsymbol{S}\left({ }^{W} \boldsymbol{R}_{C R}(\boldsymbol{q}) \boldsymbol{r}_{M}\right) \boldsymbol{J}_{O}(\boldsymbol{q}) \\
-\frac{1}{2}\left[\eta_{M} \boldsymbol{I}-\boldsymbol{S}\left(\boldsymbol{\epsilon}_{M}\right)\right] \boldsymbol{R}_{W}(\boldsymbol{q}) \boldsymbol{J}_{O}(\boldsymbol{q})
\end{array}\right] \dot{\boldsymbol{q}} } \\
& +\left[\begin{array}{cc}
\boldsymbol{R}_{W}(\boldsymbol{q}) & 0 \\
0 & \frac{1}{2}\left[\eta_{M} \boldsymbol{I}-\boldsymbol{S}\left(\boldsymbol{\epsilon}_{M}\right)\right] \boldsymbol{R}_{W}(\boldsymbol{q})
\end{array}\right]\left[\begin{array}{c}
{ }^{W} \dot{\boldsymbol{r}}_{M} \\
{ }^{W} \boldsymbol{\omega}_{M}
\end{array}\right] \\
= & \boldsymbol{J}_{M}\left(\boldsymbol{q}, \boldsymbol{\psi}_{M}\right) \dot{\boldsymbol{q}}+\boldsymbol{J}_{N}(\boldsymbol{q})^{W} \dot{\boldsymbol{\phi}}_{M}
\end{aligned}
$$

で表される (付録 2 参照)。上式は, カメラ座標内に表れる物体の 速度の運動学であり, ダイナミクスは含んではいない. 式 (26) を用いれば, $\Sigma_{C R}$ から見た対象物の速度/姿勢速度 $\left[\dot{\boldsymbol{r}}_{M}^{T}, \dot{\boldsymbol{\epsilon}}_{M}^{T}\right]^{T}$ とマニピュレータの関節速度 $\dot{\boldsymbol{q}}$ の関係が $\boldsymbol{J}_{M}\left(\boldsymbol{q}, \boldsymbol{\psi}_{M}\right)$ で, 対 象物の実際の速度 /角速度 $\left[{ }^{W} \dot{\boldsymbol{r}}_{M}^{T},{ }^{W} \boldsymbol{\omega}_{M}^{T}\right]^{T}$ との関係が $\boldsymbol{J}_{N}(\boldsymbol{q})$ でそれぞれを区別して表現できる。

ここで, ${ }^{W} \dot{\phi}_{M}$ を推定することは対象物の運動の推定であり 重要であるが, 対象物の運動を支配する方程式の推定と本質的 に等価であり,ここでは議論しない.これに対し， $\dot{\boldsymbol{q}}$ は容易に 観測可能であり, $\boldsymbol{J}_{M}\left(\boldsymbol{q}, \boldsymbol{\psi}_{M}\right) \dot{\boldsymbol{q}}$ によって生じる影響を補償して 認識特性を改善することは, 現実的であり有効である. 以下で は式（26）の右辺第二項を無視した次式について考える

$$
\dot{\boldsymbol{\psi}}_{M}=\boldsymbol{J}_{M}\left(\boldsymbol{q}, \boldsymbol{\psi}_{M}\right) \dot{\boldsymbol{q}} .
$$

式 (27) より $\dot{\boldsymbol{q}}$ を用いて画像中の対象物の動きを予測するこ とができるが，以下に問題点について考察する. 式（27）より $\boldsymbol{J}_{M}$ は $\boldsymbol{q}, \boldsymbol{\psi}_{M}$ の関数であることが分かる. $\boldsymbol{q}$ の観測は容易であ り, 誤差を含まないと考えることができるが, $\boldsymbol{\psi}_{M}(t)$ は $\Sigma_{C R}$ で表された対象物の時刻 $t$ における位置／姿勢であり, “1-Step GA”によりモデルベーストマッチングを行うことで得られた三 次元計測 [15] [16] の結果, 推定できる量である.このため誤差 を含む観測結果であることを表現するため $\hat{\boldsymbol{\psi}}_{M}$ と表し， $\boldsymbol{J}_{M}$ は $\hat{\boldsymbol{J}}_{M}\left(\boldsymbol{q}, \hat{\boldsymbol{\psi}_{M}}\right)$ と表す.

以上より, 時刻 $(t+\Delta t)$ の対象物の位置/姿勢を

$$
\hat{\boldsymbol{\psi}}_{M}(t+\Delta t)=\hat{\boldsymbol{\psi}}_{M}(t)+\hat{\boldsymbol{J}}_{M}\left(\boldsymbol{q}(t), \hat{\boldsymbol{\psi}}_{M}(t)\right) \dot{\boldsymbol{q}}(t) \Delta t
$$

となる。 


$$
\text { クォータニオンを用いたフィードフォワードオンラインポーズ遺伝的認識法 }
$$

と予測することができる. 右辺第一項の基準点という意味でも, 第二項の増分という意味でも, 観測結果 $\hat{\boldsymbol{\psi}}_{M}$ が予測位置/姿 勢に影響を与えることが分かる.この結果は, $\hat{\psi}_{M}(t)$ の推定䛊 差が $\Delta t$ 秒後の時刻 $t+\Delta t$ の位置/姿勢計測の誤差生成要因 となり, 計測誤差が指数関数的に増大する可能性を示している. 式（27）は解析的に得られた運動学関係式であるため, 上記の 好ましくない結果は三次元位置/姿勢計測のなかに含まれる難 しさと考えることができる。 この問題点に関して, 本報の推定 值 $\hat{\boldsymbol{\psi}}_{M}(t)$ に基づいた観測は, “1-Step GA” 実時間遺伝的認識 法[18] を用いているため, ヒューリステックな探索も含まれて いる.これにより，上記の誤差の連鎖の悪循環を立ち切ること ができ，推定を正確に保つことができる可能性がある。

本研究に抒ける GA の個体の位置/姿勢情報を表す遺伝子情 報 $\hat{\boldsymbol{\psi}}^{i}{ }_{M, G A, j}(i$ : 世代数, $j$ ：ある個体）を下のように示す.

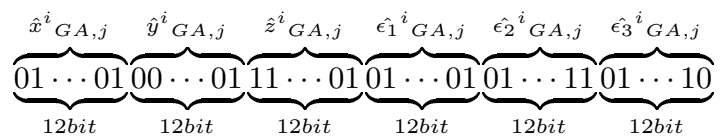

$\hat{\boldsymbol{\psi}}^{i}{ }_{M, G A, j},(j=1,2, \cdots, 30)$ の 30 個の遺伝子のなかで最大の適 合度を与える遺伝子を $\hat{\boldsymbol{\psi}}^{i}{ }_{M}$ と表す. $\hat{\boldsymbol{\psi}}^{i}{ }_{M}$ が現在の真值 $\boldsymbol{\psi}_{M}(t)$ の最も正確な測定值である.

ここでは，後のシミュレーションでの結果を分かりやすくす るため, 予測に基づいて進化した遺伝子を $\hat{\boldsymbol{\psi}}^{\star i}{ }_{M, G A, j}$ と表し, 予測を用いないときの $\hat{\boldsymbol{\psi}}^{i}{ }_{M, G A, j}$ と区別する. 同様に予測を用 いる場合の 30 個遺伝子のなかで最大の適合度を与える遺伝子 を $\hat{\boldsymbol{\psi}}^{\star i}{ }_{M}$ と表し，予測を用いない場合の $\hat{\boldsymbol{\psi}}^{i}{ }_{M}$ と区別する。 こ

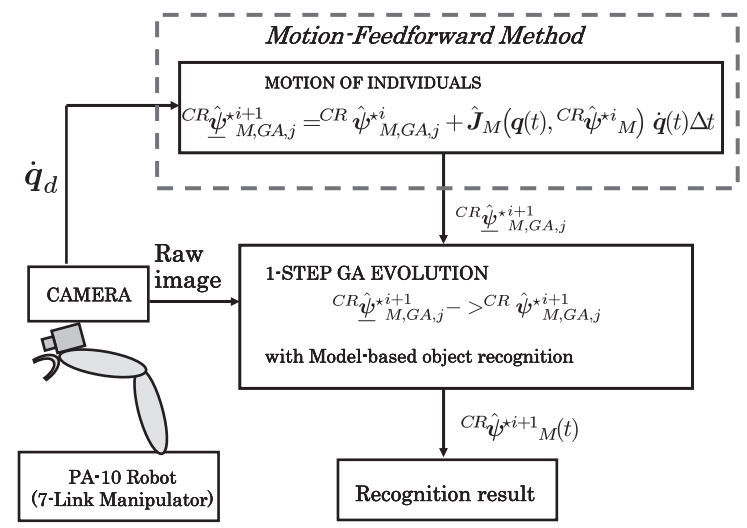

Fig. 2 Feedforward recognition system
れを用いると，式（28）は

$$
\underline{\hat{\boldsymbol{\psi}}}_{M, G A, j}^{\star i+1}=\hat{\boldsymbol{\psi}}_{M, G A, j}^{\star i}+\hat{\boldsymbol{J}}_{M}\left(\boldsymbol{q}(t), \hat{\boldsymbol{\psi}}_{M}^{\star i}\right) \dot{\boldsymbol{q}}(t) \Delta t .
$$

と表される。“1-Step GA”の進化のオペレーションを $\hat{\boldsymbol{\psi}}^{i}{ }_{M, G A, j} \rightarrow \hat{\boldsymbol{\psi}}_{M, G A, j}^{i+1}$ の矢印で表す。 これに対して, MFF 認識法の GA の進化は式 (29) で与えられる予測位置/姿勢 $\underline{\hat{\psi}}_{M, G A, j}^{\star i+1}$ に基づき, $\underline{\hat{\psi}}_{M, G A, j}^{\star i+1} \rightarrow \hat{\boldsymbol{\psi}}_{M, G A, j}^{\star i+1}$ と表される. $\widehat{\hat{\psi}}_{M, G A, j}^{\star i+1}$ の遺伝子のなかで最大の適合度を与える遺伝子は $\hat{\boldsymbol{\psi}}_{M}^{\star}{ }^{i+1}$ である.

MFF 予測法を使う認識システムを Fig. 2 に示す。式 (29) を用いて予測したカメラ座標内の対象物の運動速度で GA の個 体全体をカメラ速度を補償する方向に動かすことで, カメラの 動きによる認識への影響を抑える. “1-Step GA”では, 同じ遺 伝子が動画像に対して進化する。しかし, “MFF+1-Step GA" (MFF 予測法を使う認識法) では, 画像フレーム間の “1-Step GA” の進化の間にハンドの運動が画像中の対象物の運動に与え る影響を反映させるフィードフォード計算が入り, 付加されて いる，いずれの場合に扔いても，同じ遺伝子が進化を続ける。

$$
\text { 6. シミュレーション }
$$

\section{1 シミュレータの作成}

マニピュレータの運動は, Table 2 のパラメータを用い, 式（9）の運動方程式を時間刻み幅 $0.002[\mathrm{~s}]$ で数值積分して生 成する。この順動力学計算はニュートンオイラー法を用いた 逆動力学計算を利用することで式（9）を陽に求めることなく 得ることができる $[27]$. コントローラは式（10）の PD 制御 であり, ゲインは $\boldsymbol{D}_{p}=[500,500,400,250,150,150,150]^{T}$, $\boldsymbol{D}_{d}=[10,10,8,5,3,3,3]^{T}$ と与えた. PA10 のリンク長, 重心 位置, 質量, リンク慣性に関する物理パラメーターを Table 2 に示す。

表示には, “OpenGL”と呼ばれる三次元グラフィックスを用い た. Fig. 3 (a) に作成した表示画面を示す. PA10の手先にステ レオカメラを取り付け, 対象物を観測する. 対象物は, 各面に赤, 緑，青の色を持ち，大きさは $100[\mathrm{~mm}] \times 150[\mathrm{~mm}] \times 250[\mathrm{~mm}]$ に設定した長方体である。 ステレオカメラは，SONY 製のカ メラ CCD-TRV86（撮影素子：1/6 インチ CCD, 焦点距離 : $f=3.6[\mathrm{~mm}]$, 視野角 : $\alpha=38[\mathrm{deg}])$ と一致するように設定 する. Fig. 3 (a) にシミュレータシステムの各座標関係を示す.

Table 2 Physical parameters of the PA-10

\begin{tabular}{ccccccccc}
\hline Joint & Base & Link 1 & Link2 & Link3 & Link4 & Link5 & Link6 & Link7 \\
\hline Length $[\mathrm{m}]$ & 0.200 & 0.115 & 0.307 & 0.143 & 0.225 & 0.245 & 0.080 & 0.020 \\
Center of mass $[\mathrm{m}]$ & 0.0750 & -0.0518 & 0.0633 & 0.0536 & 0.0461 & 0.0803 & -0.0186 & 0.0040 \\
mass $[\mathrm{kg}]$ & 3.04 & 9.78 & 8.41 & 3.51 & 4.31 & 3.45 & 1.70 & 0.36 \\
Inertia moment & & & & & & & \\
$I_{x x}\left[\mathrm{kgm}^{2}\right]$ & $N / A$ & $1.23 \times 10^{-2}$ & $6.86 \times 10^{-2}$ & $3.70 \times 10^{-2}$ & $2.79 \times 10^{-2}$ & $4.07 \times 10^{-2}$ & $1.09 \times 10^{-2}$ & $2.50 \times 10^{-3}$ \\
$\begin{array}{c}\text { Inertia moment } \\
I_{y y}\left[\mathrm{kgm}^{2}\right]\end{array}$ & $N / A$ & $6.36 \times 10^{-2}$ & $6.86 \times 10^{-2}$ & $2.62 \times 10^{-2}$ & $2.79 \times 10^{-2}$ & $5.83 \times 10^{-3}$ & $1.09 \times 10^{-2}$ & $2.50 \times 10^{-3}$ \\
Inertia moment $_{I_{z z}\left[\mathrm{kgm}^{2}\right]}$ & $N / A$ & $1.23 \times 10^{-1}$ & $1.19 \times 10^{-2}$ & $3.70 \times 10^{-2}$ & $6.48 \times 10^{-3}$ & $4.07 \times 10^{-2}$ & $6.97 \times 10^{-4}$ & $1.74 \times 10^{-4}$ \\
\hline
\end{tabular}




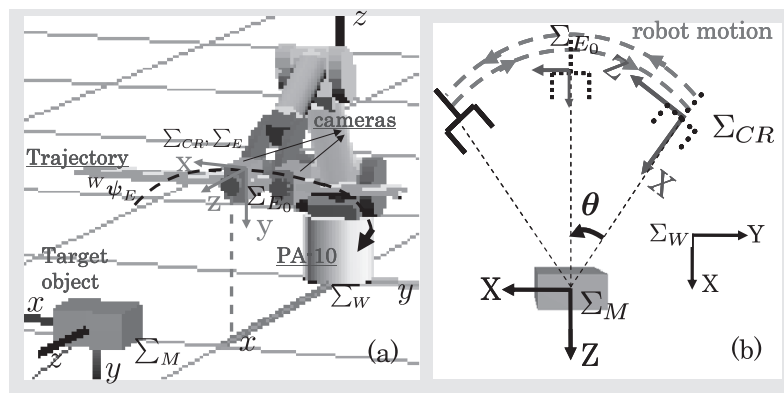

Fig. 3 (a) Simulation experiment system created by OpenGL (b) Coordinate systems of simulation experiment

Table 3 GA Parameters

\begin{tabular}{||c|c||}
\hline Population size & 30 individuals \\
\hline Selection rate & 0.5 \\
\hline Crossover & Two-point \\
\hline Mutation rate & 0.10 \\
\hline Elitist model & yes \\
\hline
\end{tabular}

製作したシミュレータでは GA一世代の進化は約 $0.14[\mathrm{~s}]$ か かっているが, $33[\mathrm{~ms}]$ で完了することを仮定する. GA の遺伝 子の数を増やすことで, 最適化の速度を上げる方法も考えられ るが，これは GA の進化に要する計算時間の増加をもたらすた め計測時間遅れが増加し, むだ時間の増大によって制御系の安 定性が損なわれる可能性がある。進化時間の短縮は，実機の制 御では複数のコンピュータを並列に用いることで，GA一世代 の進化を $33[\mathrm{~ms}]$ 以下に減少させることを想定している．GAの パラメータを Table 3 に示す.

ここでは手先にカメラを装着したマニピュレータがあらかじ め設定した目標軌道上を動きながら, 対象物を認識するシミュ レーションを行い, 提案したクォータニオンを用いた MFF 実 時間認識方法の有効性について確認する。マニピュレータは, Fig. 3 (b) に示すように往復並進/回転運動という目標軌道を設 定する. ハンドの手先の初期位置の座標系 $\Sigma_{E_{0}}$ は $\Sigma_{W}$ に固定 されている. ここで $\Sigma_{E_{0}}$ から $\Sigma_{W}$ への同次変換行列 ${ }^{W} \boldsymbol{T}_{E_{0}}$ は

$$
{ }^{W} \boldsymbol{T}_{E_{0}}=\left[\begin{array}{cccc}
0 & 0 & 1 & 918 \\
-1 & 0 & 0 & 0 \\
0 & -1 & 0 & 455 \\
0 & 0 & 0 & 1
\end{array}\right] .
$$

と設定する. $\Sigma_{E_{0}}$ で表したハンドの手先の目標軌道は

$$
\left\{\begin{aligned}
{ }^{E_{0}} x_{E d}(t) & =d * \sin \theta_{d}(t) \\
{ }^{E_{0}} y_{E d}(t) & =0 \\
{ }^{E_{0}} z_{E d}(t) & =d-d * \cos \theta_{d}(t) \\
{ }^{E_{0}} \epsilon_{1 E d}(t) & =0 \\
{ }^{E_{0}} \epsilon_{2 E d}(t) & =\sin \frac{\theta_{d}(t)}{2} \\
{ }^{E_{0}} \epsilon_{3 E d}(t) & =0
\end{aligned}\right.
$$

となる. ハンドの手先と対象物の目標距離 $d=800[\mathrm{~mm}]$, 八 ンドの手先の回転目標角度 $\theta_{d}(t)=15 \sin (\omega t)[\mathrm{deg}]$ と設定し, 山はマニピュレータの角周波数である. 式（31）より式（30）

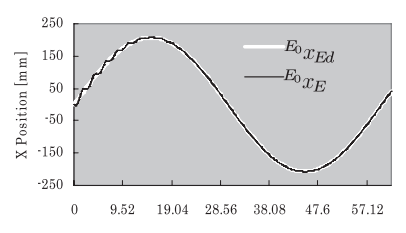

(a)

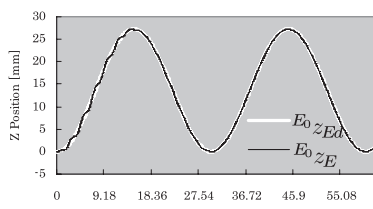

(c)

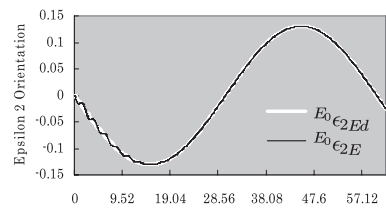

(e)

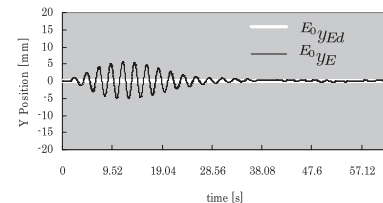

(b)

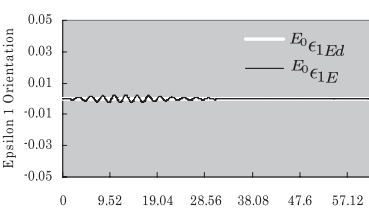

(d)

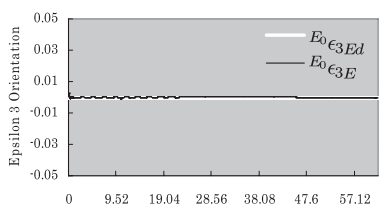

(f)
Fig. 4 Desired hand trajectory ${ }^{E_{0}} \boldsymbol{\psi}_{E d}(t)$ and the actual trajectory ${ }^{E_{0}} \boldsymbol{\psi}_{E}(t)$ with dynamics, $\omega=0.105[\mathrm{rad} / \mathrm{s}]$

を用いることで， $\Sigma_{W}$ で表したハンドの手先の目標軌道は

$$
{ }^{W} \boldsymbol{T}_{E d}(t)={ }^{W} \boldsymbol{T}_{E_{0}}{ }^{E_{0}} \boldsymbol{T}_{E d}(t) .
$$

となる. Fig. 4 に 2 章で説明した $\mathrm{PD}$ 制御による $\Sigma_{E_{0}}$ で表した ハンドの手先の目標軌道 ${ }^{E_{0}} \boldsymbol{\psi}_{E d}(t)$ と実際の手先軌道 ${ }^{E_{0}} \boldsymbol{\psi}_{E}(t)$ を示す $(\omega=0.105[\mathrm{rad} / \mathrm{s}])$ ．マニピュレータのダイナミクスの ため実際の手先軌道には振動がある. Fig. $4(\mathrm{~d})$ より $\Sigma_{E}$ の $x$ 軸回りの姿勢 $\epsilon_{1}$ が \pm 0.005 程度振動していることが分かる。 こ の振動はカメラ座標 $\Sigma_{C R}$ 内では上下方向に $\pm 13.5[\mathrm{~mm}]$ の振 幅の見かけ上の運動を発生させる.ささらに (b) に示す $\Sigma_{E}$ の $y$ 方向（この方向は Fig. 3 より $\Sigma_{W}$ の $z$ 軸方向を意味する）の $\pm 5[\mathrm{~mm}]$ 程度の振動を加えると, 振幅 $\pm 18.5[\mathrm{~mm}]$, 周期 $2.4[\mathrm{~s}]$ の見かけ上の対象物の運動が発生する.この運動はマニピュレー タのダイナミクスが作り出した偽の対象物の運動である.

対象物はハンドの手先の初期位置/姿勢での $\Sigma_{C R}$ 内に $\boldsymbol{\psi}_{M}(0)=[0,155[\mathrm{~mm}], 800[\mathrm{~mm}], 0,0,0]^{T}$ に設定した. 本シ ミュレーションでは対象物が $\Sigma_{W}$ 内で静止していることを仮定 している.

\section{2 誤差の評価}

GA の適合度 $F$ の $i$ 世代の最大值を $F_{M}^{i}$ とし, 時刻を $t_{1}$, $t_{2}, \cdots, t_{n}$ と定める。このとき

$$
\bar{F}=\frac{1}{n} \sum_{i=1}^{n} F_{M}^{i}\left(\hat{\boldsymbol{\psi}}_{M}^{i}\left(t_{i}\right)\right)
$$

を適合度の時間平均值と定義する。 また, 探索された対象物 の位置/姿勢 $\hat{\boldsymbol{\psi}}_{M}^{i}$ と, 真の位置/姿勢 $\boldsymbol{\psi}_{M}$ との差を認識の 位置/姿勢誤差 $\Delta \boldsymbol{\psi}_{M}$ と定義し, $\Delta \boldsymbol{\psi}_{M}=\left[\boldsymbol{\psi}_{M}^{T}-\hat{\boldsymbol{\psi}}_{M}^{i T}\right]^{T}=$ $\left[\Delta x_{M}, \Delta y_{M}, \Delta z_{M}, \Delta \epsilon_{1 M}, \Delta \epsilon_{2 M}, \Delta \epsilon_{3 M}\right]^{T}$ と表す. 位置/姿勢 の誤差の rms 值 (root-mean-square value) $\Delta \tilde{\psi}_{M}$ は, 


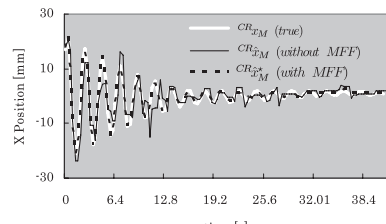

(a)

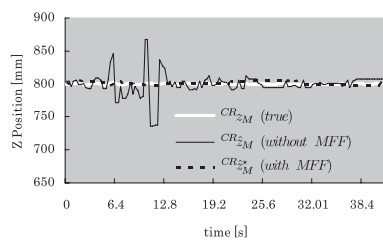

(c)

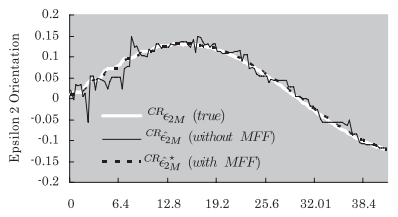

(e)

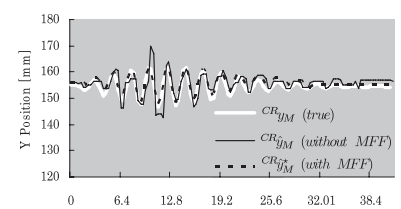

time

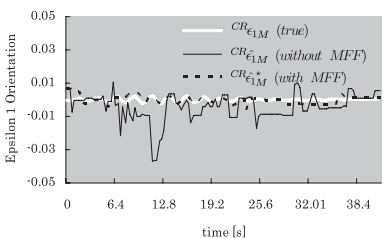

(d)



(f)
Fig. 5 Comparison of the recognition by "1-step GA" $\hat{\boldsymbol{\psi}}_{M}$ and by "MFF + 1-step GA" $\hat{\boldsymbol{\psi}}^{\star}{ }_{M}$ under $\omega=0.105[\mathrm{rad} / \mathrm{s}]$

$$
\begin{gathered}
\Delta \tilde{\boldsymbol{\psi}}_{M}=\left[\Delta{\tilde{x_{M}}}, \Delta \tilde{y}_{M}, \Delta \tilde{z}_{M},\right. \\
\left.\Delta \tilde{\epsilon}_{M}, \Delta \tilde{\epsilon}_{M}, \Delta \tilde{\epsilon}_{M}\right]^{T} \\
\Delta \tilde{p}_{M}=\sqrt{\frac{1}{n} \sum_{i=1}^{n}\left(\Delta p_{M}\left(t_{i}\right)\right)^{2}},\left(p=x, y, z, \epsilon_{1}, \epsilon_{2}, \epsilon_{3}\right) .
\end{gathered}
$$

と定義する.

本シミュレーションでは $0[\mathrm{~s}]$ から $40[\mathrm{~s}]$ までの各世代の最大 適合度の時間平均值 $\bar{F}$ と位置/姿勢の誤差の $\mathrm{rms}$ 值 $\Delta \tilde{\boldsymbol{\psi}}_{M}$ を 用いて認識性能を評価する。クォータニオンで姿勢を表すとき, 変数 $\epsilon_{1}, \epsilon_{2}, \epsilon_{3}$ は比を表しているため, 単位は無次元である. さ らに\|情は $\eta$ に依存しているため他の表現に比べて姿勢の定 量的評価が難しい，そこで参考のために変換の一例をあげてお く. 対象物が $x$ 軸回りに角度 1 [deg] で回転した姿勢はクォー タニオンで表すと $\epsilon_{1}=0.008, \epsilon_{2}=0, \epsilon_{3}=0$ になる.

\section{3 シミュレーション}

上述の目標軌道でマニピュレータの角周波数 $\omega=0.105,0.157$, 0.314 （すなわち, 周期 $T=60[\mathrm{~s}], 40[\mathrm{~s}], 20[\mathrm{~s}]$ ）を与えた。 こ の条件でマニピュレータを動かすときに, ハンド・アイ・カメ ラから見た対象物の位置/姿勢 $\boldsymbol{\psi}_{M}(t)$ を測定する。測定性能 を MFF 予測法を使う認識法 (“MFF + 1-step GA”) と使わ ない認識法 (“1-Step GA”) と比較する.ここで, $t=0$ のと き探索対象物位置/姿勢が既知であると仮定する。

Fig. 5 はマニピュレータの角周波数を $\omega=0.105[\mathrm{rad} / \mathrm{s}]$ と設 定した場合の “1-step GA”と“MFF + 1-step GA”で比較す る結果を示した。ここでは, $\Sigma_{C R}$ で表した対象物の真值は $\boldsymbol{\psi}_{M}$,

\begin{tabular}{|c|c|c|c|c|}
\hline \multicolumn{2}{|c|}{$\bar{F}, \Delta^{C R} \tilde{\psi}_{M} \omega[\mathrm{rad} / \mathrm{s}]$} & $\omega=0.105$ & $\omega=0.157$ & $\omega=0.314$ \\
\hline $\begin{array}{l}1 \text {-step } \\
\text { GA }\end{array}$ & $\begin{array}{l}\bar{F} \\
\Delta^{C R} \tilde{x}_{M}[\mathrm{~mm}] \\
\Delta^{C R} \tilde{y}_{M}[\mathrm{~mm}] \\
\Delta^{C R} \tilde{z}_{M}[\mathrm{~mm}] \\
\Delta^{C R} \tilde{\epsilon}_{1 M} \\
\Delta^{C R} \tilde{\epsilon}_{\epsilon_{M}} \\
\Delta^{C R} \tilde{\epsilon}_{3 M}\end{array}$ & $\begin{array}{c}0.8026 \\
3.1742 \\
3.5439 \\
14.9828 \\
0.0188 \\
0.0203 \\
0.0053\end{array}$ & $\begin{array}{r}0.7371 \\
3.4841 \\
4.4271 \\
17.1283 \\
0.0251 \\
0.0323 \\
0.0072 \\
\end{array}$ & $\begin{array}{r}0.6280 \\
7.6398 \\
21.7151 \\
33.8106 \\
0.0494 \\
0.0656 \\
0.0091\end{array}$ \\
\hline $\begin{array}{l}\text { MFF } \\
+ \\
1 \text {-step } \\
\text { GA }\end{array}$ & $\begin{array}{l}\bar{F} \\
\Delta^{C R} \tilde{x}_{M}[\mathrm{~mm}] \\
\Delta^{C R} \tilde{y}_{M}[\mathrm{~mm}] \\
\Delta^{C R} \tilde{z}_{M}[\mathrm{~mm}] \\
\Delta^{C R} \tilde{\epsilon}_{1 M} \\
\Delta^{C R} \tilde{\epsilon}_{\varepsilon_{M}} \\
\Delta^{C R} \tilde{\epsilon}_{3 M}\end{array}$ & $\begin{array}{l}0.9806 \\
0.6235 \\
1.16 \\
2.8536 \\
0.0075 \\
0.0091 \\
0.0022\end{array}$ & $\begin{array}{r}0.9764 \\
1.49 \\
1.712 \\
5.5322 \\
0.008 \\
0.0092 \\
0.002\end{array}$ & $\begin{array}{r}0.9733 \\
1.5601 \\
1.7493 \\
5.281 \\
0.0086 \\
0.0098 \\
0.0029\end{array}$ \\
\hline
\end{tabular}
“1-step GA” で認識した対象物の位置/姿勢は $\hat{\boldsymbol{\psi}}_{M}$, “MFF +
Table 4 Conclusion of simulations

1-step GA”で認識した対象物の位置/姿勢は $\hat{\boldsymbol{\psi}}^{\star}{ }_{M}$ と表す。口 ボットマニピュレータのダイナミクスのため実際の手先軌道に は振動がある. Fig. 4 に示すように, 目標軌道 ${ }^{E_{0}} \boldsymbol{\psi}_{E d}$ を与え るとき, 実際の手先軌道 ${ }^{E_{0}} \boldsymbol{\psi}_{E}$ が $0[\mathrm{~s}]-30[\mathrm{~s}]$ の間に周期約 $2[\mathrm{~s}]$ のハンド過渡応答が見られる。 そのため, カメラから見た 対象物も $0[\mathrm{~s}]-30[\mathrm{~s}]$ の間に振動を発生している. Fig. 5 の白 い線で表した $\psi_{M}$ はこの振動を示している. ダイナミクスの影 響による不規則運動する対象物の認識は難しい. Fig. 5 に示し た“1-step GA”による認識した $\hat{\boldsymbol{\psi}}_{M}$ と“MFF + 1-step GA” で認識した $\hat{\boldsymbol{\psi}}^{\star}{ }_{M}$ と比較すると, 真值 $\boldsymbol{\psi}_{M}$ に追従しているの は MFF 法を用いた $\hat{\boldsymbol{\psi}}^{\star}{ }_{M}$ であり, “1-step GA” のみの $\hat{\boldsymbol{\psi}}_{M}$ は大きな誤差を含んでいる。 また $\hat{\boldsymbol{\psi}}^{\star}{ }_{M}$ の結果は周期約 $2[\mathrm{~s}]$ の ロボットハンドの過渡応答の影響を減少させ, ほぼ真值と一致 している. 対象物は $\Sigma_{C R}$ の $z$ 軸の $800[\mathrm{~mm}]$ 程度のところに 置いているので, $z$ 軸の認識分解度が $x, y$ 軸より低いという理 由で, $z$ の方向の誤差が $x, y$ 方向より大きい. Fig. 5 の条件の 3D ポーズ計測誤差の rms 值を Table 4 の $\omega=0.105$ の列に まとめている。この結果より MFF を用いるほうが明らかに誤 差が少ない。つまり，ハンド・アイ・カメラを用いる認識は八 ンドの運動からの影響を受けなく, カメラが動いても，ロバス 卜認識できると確認した。

次にマニピュレータの角周波数を $\omega=0.157[\mathrm{rad} / \mathrm{s}], \omega=$ $0.314[\mathrm{rad} / \mathrm{s}]$ とそれぞれ設定する。 マニピュレータの手先の運 動は速ければ速いほどカメラから見る対象物の振動が大きくな る (Fig. 6 と Fig. 7 に示した). “1-step GA” 認識法と “MFF + 1-step GA” 認識法と比較すると, “1-step GA” 認識法だけ を用いた認識は, ダイナミクスの振動がある場合認識のずれが 大きくなって, 対象物を追従するのが難しくなる. 特に, Fig. 7 に示す $\omega=0.314[\mathrm{rad} / \mathrm{s}]$ の場合は $0-25[\mathrm{~s}]$ の間にダイナミク スの振動が大きすぎて対象物を認識できない状態になった。そ れは GA の認識速度がカメラから見た対象物の速度より遅くな ることが理由であると考える。しかし, “MFF + 1-step GA” 認識法を用いると、、ニピュレータの運動速度が速くなり, そ のためダイナミクスの振動が大きくなっても, ダイナミクスか ら認識への影響を補償して安定して認識できると示した。 


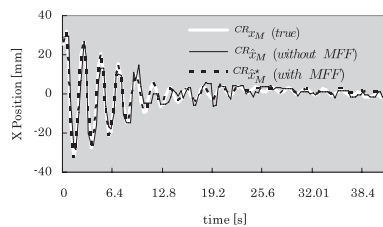

(a)

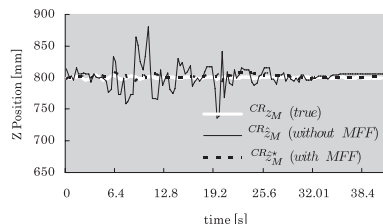

(c)

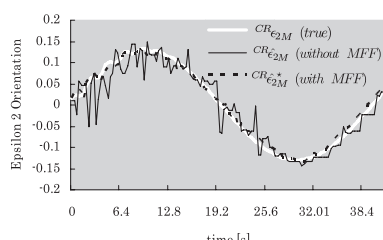

(e)

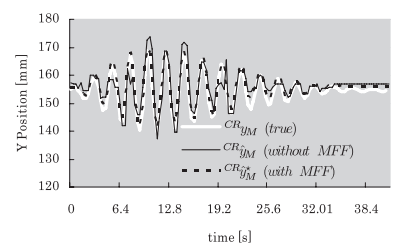

(b)

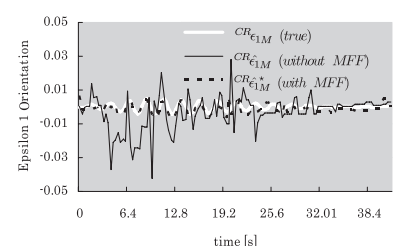

(d)

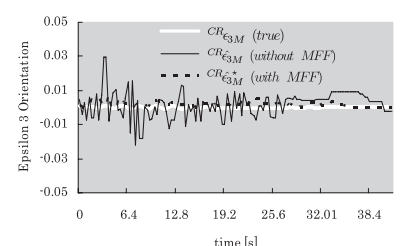

(f)
Fig. 6 Comparison of the recognition by "1-step GA" $\hat{\boldsymbol{\psi}}_{M}$ and by "MFF + 1-step GA" $\hat{\boldsymbol{\psi}}^{\star}{ }_{M}$ under $\omega=0.157[\mathrm{rad} / \mathrm{s}]$

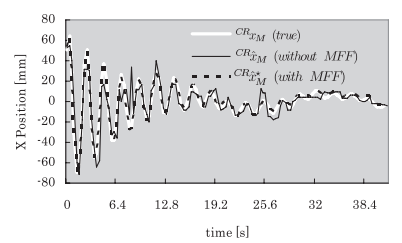

(a)

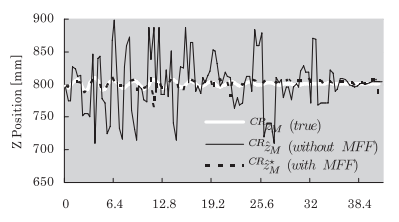

(c)

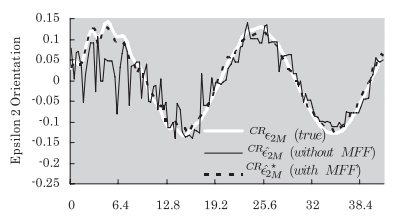

(e)

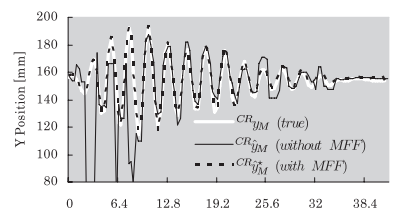

(b)

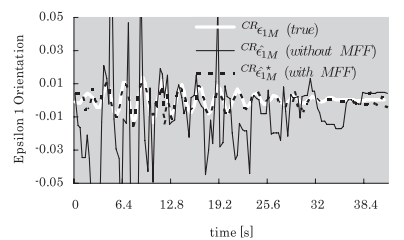

(d)

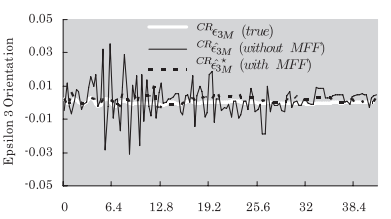

(f)
Fig. 7 Comparison of the recognition by "1-step GA" $\hat{\boldsymbol{\psi}}_{M}$ and by "MFF + 1-step GA" $\hat{\boldsymbol{\psi}}^{\star}{ }_{M}$ under $\omega=0.314[\mathrm{rad} / \mathrm{s}]$

Table 4 は異なるハンド周期運動の角周波数 $\omega$ でのシミュレー ションの $\bar{F}$ と $\Delta \tilde{\psi}_{M}$ を計算してまとめた結果である. MFFを 用いない“1-step GA” だけで認識する場合はマニピュレータの 角周波数 $\omega$ は $0.105[\mathrm{rad} / \mathrm{s}]$ から $0.314[\mathrm{rad} / \mathrm{s}]$ まで増加すると ともに, 各世代の最大適合度の平均值 $\bar{F}$ は小さくなって, 位置 $/$ 姿勢の誤差の $\mathrm{rms}$ 值 $\Delta \tilde{\boldsymbol{\psi}}_{M}$ は大きくなる. 最大位置誤差の $\mathrm{rms}$
值は約 $33[\mathrm{~mm}]$, 最大姿勢誤差の $\mathrm{rms}$ 值は約 8 [deg] になって しまう。つまり，認識の性能はだんだん低くなる。“1-step GA +MFF”を用いるとき, マニピュレータの運動速度が速くなっ ても, $\bar{F}$ と $\Delta \tilde{\boldsymbol{\psi}}_{M}$ はあまり変化せず, 高い $\bar{F}$ と低い $\Delta \tilde{\boldsymbol{\psi}}_{M}$ を 維持することができる。これにより提案した $\mathrm{MFF}$ 認識方法の 有効性を確認した.

\section{7. 結 論}

本研究では, 動画像中から対象物の位置/姿勢 6 変数を同時 に認識することを目的として，モデルベーストマッチング法と GA およびクォータニオンを用いた三次元位置/姿勢計測法を 提案した。 さらに, マニピュレータの手先に CCD カメラが装 着されるアイ・イン・ハンドシステムで, マニピュレータのダ イナミクスが対象物認識に与える影響を解析し, これを抑える ために MFF 認識方法を提案し, その有効性を示した.

将来的には, 実際にロボットマニピュレータによる対象物（六 変数) へのビジュアルサーボを行いたい. MFF 認識法を用い ることでロボットが物体の真の運動と自分の動きから発生する 相対的な運動を区別でき, 安定な認識性能を得ることで, 安定 な 3D ポーズビジュアルサーボの実現に向けた研究を進めたい.

\section{参 考 文 献}

[1] S. Hutchinson, G. Hager and P. Corke: "A Tutorial on Visual Servo Control," IEEE Trans. on Robotics and Automation, vol.12, no.5, pp.651-670, 1996.

[2 2 P.Y. Oh and P.K. Allen: "Visual Servoing by Partitioning Degrees of Freedom," IEEE Trans. on Robotics and Automation, vol.17, no.1, pp.1-17, 2001.

[3] E. Malis, F. Chaumentte and S. Boudet: "2-1/2-D Visual Servoing," IEEE Trans. on Robotics and Automation, vol.15, no.2, pp.238-250, 1999.

[4] P.K. Allen, A. Timchenko, B. Yoshimi and P. Michelman: "Automated Tracking and Grasping of a Moving object with a Robotic Hand-Eye System," IEEE Trans. on Robotics and Automation, vol. 9, no. 2, pp.152-165, 1993.

[5] 橋本, 木村 : “ビジュアルサーボイング一非線形オブザーバアプロー チー”, 日本ロボット学会誌, vol.13, no.7, pp.986-993, 1995.

[6] A. De Luca, G. Oriolo and P. R. Giordano: "On-line Estimation of Feature Depth for Image-Based Visual Servoing Schemes," IEEE Int. Conf. on Robotics and Automation (ICRA2007), 2007.

[ 7 ] 中坊, 石川：“1 ms 高速ビジョンを用いたビジュアルサーボイング”, 計測と制御, vol.40, no.9, pp.636-640, 2001.

[ 8 ] 石井, 石川："1 ms ビジュアルフィードバックシステムのための高速対象 追跡アルゴリズム”, 日本ロボット学会誌, vol.17, no.2, pp.195-201, 1999.

[9] 石川, 角, 富田：“ステレオビジョンによる三次元物体の三次元運動 追跡”, 日本ロボット学会誌, vol.18, no.2, pp.213-220, 2000.

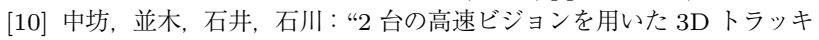
ング”, 機械システム制御シンポジウム講演論文集, pp.78-81, 2002.

[11] S. Niyogi and W.T. Freeman: "Example-based head tracking," Technical Report TR96-34, MERL Cambridge Research, 1996.

[12] L. Masson, M. Dhome and F. Jurie: "Robust Real Time Tracking of 3D Objects," Proc. 17th IEEE Int. Conf. on Patten Recognition, 2004.

[13] S. Yamane, M. Izumi and K. Fukunaga: "A Method of ModelBased Pose Estimation," IEICE, vol.J79-D-2, no.2, pp.165-173, 1996.

[14] F. Toyama, K. Shoji and J. Miyamichi: "Pose Estimation from a Line Drawing Using Genetic Algorithm," IEICE, vol.J81-D-2, 
no.7, pp.1584-1590, 1998.

[15] W. Song, Y. Mae and M. Minami: "Evolutionary Pose Measurement by Stereo Model Matching," Journal of Advanced Computational Intelligence and Intelligent Informatics, vol.9, no.2, pp.150-157, 2005.

[16] W. Song, M. Minami, Y. Mae and S. Aoyagi: "On-line Evolutionary Head Pose Measurement by Feedforward Stereo Model Matching," IEEE Int. Conf. on Robotics and Automation (ICRA), pp.4394-4400, 2007.

[17] B. Siciliano and L. Villani: Robot Force Control. Kluwer Academic Publisher, 1999.

[18] H. Suzuki and M. Minami: "Visual Servoing to catch fish Using Global/local GA Search," IEEE/ASME Transactions on Mechatronics, vol.10, issue 3, pp.352-357, 2005.

[19] S. Baker and I. Mattews: "Equivalence and efficiency of image alignment algorithms," Proceedings of IEEE Conference on Computer Vision and Pattern Recognition, pp.1090-1097, 2001.

[20] H.Y. Shum and R. Szeliski: "Construction of panoramic image mosaics with global and local alignment," International Journal of Computer Vision, vol.16, no.1, pp.63-84, 2000.

[21] E. Mails: "Improving vision-based control using efficient second-order minimization techniques," Proceedings of IEEE International Conference on Robotics and Automation, pp.1843-1848, 2004.

[22] S. Benhimane and E. Mails: "Real-time image-based tracking of planes using efficient second-order minimization," Proceedings of IEEE/RSJ Conference on Intelligent Robot and Systems, pp.1090-1097, 2004.

[23] Y. Keller and A. Averbuch: "Fast motion estimation using bidirectional gradient methods," IEEE Transactions on Image Processing, vol.13, no.8, pp.1042-1054, 2004.

[24] S. Caccavale, C. Natale, B. Siciliano and L. Villani: "Six-DOF Impedance Control BAsed on Angle/Axis Representations," IEEE Trans. on Robotics and Automation, vol.15, no.2, 1999.

[25] B. Xian, M.S. de Queiroz, D. Dawson and I. Walker: "TaskSpace Tracking Control of Robot Manipulators via Quaternion Feedback," IEEE Trans. on Robotics and Automation, vol.20, no. 1, 2004.

[26] J.T.-Y. Wen and K. Kreutz-Delgado: "The attitude control problem," IEEE Trans. on Robotics and Automation, vol.39, pp.1148-1163, 1991

[27] 美多勉, 大須賀公一：ロボット制御工学入門. コロナ社, 1989.

\section{付録 A．式（25）の導出}

二つの座標系 $\Sigma_{A}, \Sigma_{B}$ を考え， $\Sigma_{B}$ の $\Sigma_{A}$ に対する角速度

${ }^{A} \boldsymbol{\omega}_{B}$ とし， $\Sigma_{A}$ の $\Sigma_{B}$ に対する角速度 ${ }^{B} \boldsymbol{\omega}_{A}$ とする。ここに

${ }^{A} \boldsymbol{\omega}_{B}$ と ${ }^{B} \boldsymbol{\omega}_{A}$ の関係を導く.

回転行列 ${ }^{A} \boldsymbol{R}_{B}$ は下式を満たす。

$$
{ }^{A} \boldsymbol{R}_{B}{ }^{B} \boldsymbol{R}_{A}=\boldsymbol{I},
$$

式（A.1）を時間について微分して，式

$$
\frac{d}{d t}\left({ }^{A} \boldsymbol{R}_{B}\right){ }^{B} \boldsymbol{R}_{A}+{ }^{A} \boldsymbol{R}_{B} \frac{d}{d t}\left({ }^{B} \boldsymbol{R}_{A}\right)=\mathbf{0} .
$$

を得る. $\Sigma_{B}$ で表した任意べクトル ${ }^{B} \boldsymbol{p}$ に対して $\left({ }^{A} \boldsymbol{R}_{B}{ }^{B} \boldsymbol{p}\right)$ の 時間微分を考えると

$$
\begin{aligned}
\frac{d}{d t}\left({ }^{A} \boldsymbol{R}_{B}\right){ }^{B} \boldsymbol{p} & ={ }^{A} \boldsymbol{\omega}_{B} \times\left({ }^{A} \boldsymbol{R}_{B}{ }^{B} \boldsymbol{p}\right) \\
& =\boldsymbol{S}\left({ }^{A} \boldsymbol{\omega}_{B}\right){ }^{A} \boldsymbol{R}_{B}{ }^{B} \boldsymbol{p} .
\end{aligned}
$$

よって

$$
\frac{d}{d t}\left({ }^{A} \boldsymbol{R}_{B}\right)=\boldsymbol{S}\left({ }^{A} \boldsymbol{\omega}_{B}\right){ }^{A} \boldsymbol{R}_{B} .
$$

を得る。同様に，

$$
\frac{d}{d t}\left({ }^{B} \boldsymbol{R}_{A}\right)=\boldsymbol{S}\left({ }^{B} \boldsymbol{\omega}_{A}\right)^{B} \boldsymbol{R}_{A} .
$$

を得る。式（A.4）（A.5）を式（A.2）に代入すると

$$
\boldsymbol{S}\left({ }^{A} \boldsymbol{\omega}_{B}\right)=-{ }^{A} \boldsymbol{R}_{B} \boldsymbol{S}\left({ }^{B} \boldsymbol{\omega}_{A}\right){ }^{B} \boldsymbol{R}_{A} .
$$

を得る. 式（A.6）は ${ }^{A} \boldsymbol{\omega}_{B}$ と ${ }^{B} \boldsymbol{\omega}_{A}$ の関係を示した.

付録 B. 式 $(26)$ の導出

まず式（23）（25）を式（20）に代入すると

$$
\begin{aligned}
\dot{\boldsymbol{r}}_{M}= & \boldsymbol{R}_{W}(\boldsymbol{q})\left({ }^{W} \dot{\boldsymbol{r}}_{M}-\boldsymbol{J}_{P}(\boldsymbol{q}) \dot{\boldsymbol{q}}\right) \\
& +\left[-\boldsymbol{R}_{W}(\boldsymbol{q}) \boldsymbol{S}\left(\boldsymbol{J}_{O}(\boldsymbol{q}) \dot{\boldsymbol{q}}\right)^{W} \boldsymbol{R}_{C R}(\boldsymbol{q})\right] \\
& \boldsymbol{R}_{W}(\boldsymbol{q})\left({ }^{W} \boldsymbol{r}_{M}-{ }^{W} \boldsymbol{r}_{C R}(\boldsymbol{q})\right)
\end{aligned}
$$

を得る。式（19）より

$$
{ }^{W} \boldsymbol{r}_{M}-{ }^{W} \boldsymbol{r}_{C R}(\boldsymbol{q})={ }^{W} \boldsymbol{R}_{C R}(\boldsymbol{q}) \boldsymbol{r}_{M}
$$

が成立する。 ${ }^{W} \boldsymbol{R}_{C R}(\boldsymbol{q}) \boldsymbol{R}_{W}(\boldsymbol{q})=\boldsymbol{I}$ と式（B.2）を用いて式 (B.1) は

$$
\begin{aligned}
\dot{\boldsymbol{r}}_{M}= & \boldsymbol{R}_{W}(\boldsymbol{q})\left({ }^{W} \dot{\boldsymbol{r}}_{M}-\boldsymbol{J}_{P}(\boldsymbol{q}) \dot{\boldsymbol{q}}\right) \\
& -\boldsymbol{R}_{W}(\boldsymbol{q}) \boldsymbol{S}\left(\boldsymbol{J}_{O}(\boldsymbol{q}) \dot{\boldsymbol{q}}\right)\left({ }^{W} \boldsymbol{R}_{C R}(\boldsymbol{q}) \boldsymbol{r}_{M}\right)
\end{aligned}
$$

になる。（B.3）は

$$
\begin{aligned}
\dot{\boldsymbol{r}}_{M}= & \boldsymbol{R}_{W}(\boldsymbol{q})\left({ }^{W} \dot{\boldsymbol{r}}_{M}-\boldsymbol{J}_{P}(\boldsymbol{q}) \dot{\boldsymbol{q}}\right) \\
& +\boldsymbol{R}_{W}(\boldsymbol{q}) \boldsymbol{S}\left({ }^{W} \boldsymbol{R}_{C R}(\boldsymbol{q}) \boldsymbol{r}_{M}\right) \boldsymbol{J}_{O}(\boldsymbol{q}) \dot{\boldsymbol{q}}
\end{aligned}
$$

となる. 式 (B.4) の右辺は ${ }^{W} \dot{\boldsymbol{r}}_{M}$ の項と $\dot{\boldsymbol{q}}$ の項を区別して表 すため, 式 (B.4)を

$$
\begin{aligned}
\dot{\boldsymbol{r}}_{M}= & \boldsymbol{R}_{W}(\boldsymbol{q})^{W} \dot{\boldsymbol{r}}_{M}+\left[-\boldsymbol{R}_{W}(\boldsymbol{q}) \boldsymbol{J}_{P}(\boldsymbol{q})\right. \\
& \left.+\boldsymbol{R}_{W}(\boldsymbol{q}) \boldsymbol{S}\left({ }^{W} \boldsymbol{R}_{C R}(\boldsymbol{q}) \boldsymbol{r}_{M}\right) \boldsymbol{J}_{O}(\boldsymbol{q})\right] \dot{\boldsymbol{q}}
\end{aligned}
$$

と表す.

$$
\begin{aligned}
& \text { 次に式（21）を式 }(22) \text { に代入すると } \\
& \dot{\boldsymbol{\epsilon}}_{M}=\frac{1}{2}\left[\eta_{M} \boldsymbol{I}-\boldsymbol{S}\left(\boldsymbol{\epsilon}_{M}\right)\right] \\
& \boldsymbol{R}_{W}(\boldsymbol{q})\left({ }^{W} \boldsymbol{\omega}_{M}-{ }^{W} \boldsymbol{\omega}_{C R}(\boldsymbol{q})\right)
\end{aligned}
$$

を得る。式（24）を上式に代入すると

$$
\begin{aligned}
\dot{\boldsymbol{\epsilon}}_{M}= & \frac{1}{2}\left[\eta_{M} \boldsymbol{I}-\boldsymbol{S}\left(\boldsymbol{\epsilon}_{M}\right)\right] \\
& \boldsymbol{R}_{W}(\boldsymbol{q})\left({ }^{W} \boldsymbol{\omega}_{M}-\boldsymbol{J}_{O}(\boldsymbol{q}) \dot{\boldsymbol{q}}\right)
\end{aligned}
$$

になる. 式（B.6）の右辺を ${ }^{W} \boldsymbol{\omega}_{M}$ の項と $\dot{\boldsymbol{q}}$ の項を区別して表 すと

$$
\begin{aligned}
\dot{\boldsymbol{\epsilon}}_{M}= & \frac{1}{2}\left[\eta_{M} \boldsymbol{I}-\boldsymbol{S}\left(\boldsymbol{\epsilon}_{M}\right)\right] \boldsymbol{R}_{W}(\boldsymbol{q})^{W} \boldsymbol{\omega}_{M} \\
& -\frac{1}{2}\left[\eta_{M} \boldsymbol{I}-\boldsymbol{S}\left(\boldsymbol{\epsilon}_{M}\right)\right] \boldsymbol{R}_{W}(\boldsymbol{q}) \boldsymbol{J}_{O}(\boldsymbol{q}) \dot{\boldsymbol{q}}
\end{aligned}
$$




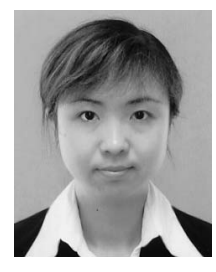

\section{宋薇 (Wei Song)}

2003 年北京信息科技大学電子信息工程学科卒業, 2006 年福井大学大学院知能システム工学専攻修士 課程修了. 2009 年福井大学大学院システム設計工 学博士課程修了. 博士 (工学). 画像認識, ビジュ アルサーボイング等の研究に従事. IEEE などの会 員.

(日本ロボット学会正会員)

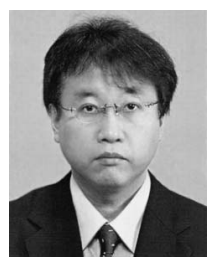

青柳誠司（Seiji Aoyagi）

1986 年東京大学工学部精密機械工学科卒業. 1988 年同修士課程修了. 同年金沢大学工学部機械システ 厶工学科助手, 1995 年同助教授. 1996 年関西大学 工学部管理工学科助教授，2003 年同教授. 現在同 大学システム理工学部機械工学科教授. 2002 年度 米国カリフォルニア工科大学 Visiting Researcher. ロボット用センサ・アクチュエータ, ロボット制御, マイクロマシン 等の研究に従事. 2002 年ファナック FA ロボット財団論文賞受賞. 博 士 (工学). 精密工学会, 日本機械学会, 電気学会, IEEE 等の会員.

（日本ロボット学会正会員）

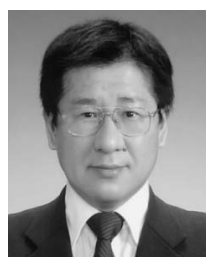

見浪 護（Mamoru Minami）

1979 年大阪府立大学航空工学科卒業, 1981 年大 阪府立大学航空工学専攻修士課程修了. 1993 年金 沢大学大学院自然科学研究科博士課程修了. 博士 (工学). 1994 年福井大学工学部機械工学科助教授, 2002 年同知能システム工学科教授, 現在に至る. ロボットの力学, 拘束運動, 力制御, 移動マニピュ レータの制御, 画像認識, ビジュアルサーボイング等の研究に従事. 日本機械学会, 計測自動制御学会, IEEE などの会員.

（日本ロボット学会正会員） 